\title{
EFFICIENT ONE POT SYNTHESIS, In-vitro ANTIOXIDANT ACTIVITIES OF Zn(II) COMPLEX WITH (E)-N1[(E)-3- PHENYLALLYLIDENE]BENZENE-1,2-DIAMINE
}

\author{
R. Selvarani ${ }^{1, \bigotimes}$, S. Balasubramaniyan ${ }^{1}$, K. Rajasekar $^{1}$, C. Veeravel $^{1}$ \\ and R. Geetha ${ }^{1}$ \\ PG \& Research Department of Chemistry, Government Arts College, Rajaji Nagar, \\ Ariyalur-621713 \\ (Affiliated to Bharathidasan University, Tiruchirappalli-620 024) \\ Tamil Nadu, India \\ ${ }^{\square}$ Corresponding Author: selvasekar2008yoki@gmail.com
}

\begin{abstract}
The Schiff base (E)-N1[(E)-3-phenylallylidene]benzene-1,2-diamine was derived from the condensation of orthophenylenediamine and cinnamaldehyde. The Schiff base and its $\mathrm{Zn}$ (II) complex were characterized based on microanalysis, conductivity, IR, UV-Visible, NMR spectral studies. The analytical data suggest the stoichiometry to be 1:1 (M:L). The molar conductance data reveal that the complex is non-electrolyte. Melting points support the thermal stability of the Schiff base. The UV spectral data support the square planar geometry of the complex. Coordination of ligand was confirmed by the constant change in FT-IR. The NMR $\left({ }^{1} \mathrm{H} \&{ }^{13} \mathrm{C}\right)$ spectra of the Schiff base and its complex were confirmed by the geometry and magnetic property them. The in-vitro antibacterial activity of the synthesized ligand and Zn(II) complex were screened for bio-potential activity using some microorganisms by agar well diffusion method. The antibacterial activity further confirmed by its pharmacokinetics study using Swiss ADME computational study. The antioxidant activity of the Schiff base and $\mathrm{Zn}$ (II) complex was also assessed by DPPH free radical scavenging method. IC50 values are also predicted and compared with standard ascorbic acid.

Keywords: Cinnamaldehyde, Schiff base, Metal Complex, Antibacterial, Antioxidant, Pharmacokinetics
\end{abstract}

RASĀYAN J. Chem., Vol. 14, No.2, 2021

\section{INTRODUCTION}

Schiff base is a multilateral ligand in which $\mathrm{C}=\mathrm{O}$ group is replaced by $\mathrm{C}=\mathrm{N}$ by the condensation of the nucleophilic nitrogen atom of amine attack to the electrophilic carbon atom of aldehyde or ketones. ${ }^{1}$ Schiff base ligands are readily formed from aldehyde than that of the ketones. It was first discovered by Hugo Schiff in $1864 .^{2}$ This ligand is chemically and biologically very important due to the presence of $\mathrm{Sp}^{2}$ hybridized nitrogen atom of azomethine group. ${ }^{3}$ Schiff base shows a vital role in organic and bioinorganic chemistry, they form the most stable complexes with transition and post-transition metal ions. ${ }^{4}$ They are important in the field of modern coordination chemistry because they have industrial, analytical, antibacterial, antifungal, anticancer, antiviral and antitubercular activities and it also shows chelating ability, catalytic and extraction properties. ${ }^{5,6}$ Antioxidants are the compounds that terminate the attack of free radicals and prevent it from aging and different diseases associate with oxidative damage inside the body system. ${ }^{7}$ Cinnamaldehyde is one of the main components of bark extract cinnamon. It is used in perfume especially natural, sweet and fruity scents they also used aroma compounds by the smell of cinnamon in almond, apricot and butterscotch. ${ }^{8}$ It is a potential anti-obesity drug due to its low toxicity, eco-friendly, food flavoring, medical herb and renowned strong adsorption properties. ${ }^{9}$ Orthophenylenediamine (OPD) is one the organic compound it undergoes condensation with carbonyl compounds (aldehyde and ketones) gives Schiff base which is used as an antioxidant in rubber product and also used in photo-luminescence, catalytic activity and pharmaceutical with various diketone. ${ }^{10}$ Zinc metal plays an important role in biologist such as absorption of calcium, formation of antibodies, thyroid gland and hormone function and it is present in brain, muscle, bones, kidney and liver. ${ }^{11}$ The present view of this paper is to the synthesis of transition metal $\mathrm{Zn}^{2+}$ ) the complex of Schiff base from cinnamaldehyde and 
RASĀYAN J. Chem.

Vol. 14 | No. 2 |861-870| April - June | 2021

Orthophenylenediamine (OPD) and characterized by various physicochemical, spectral and bio-potential studies.

\section{EXPERIMENTAL}

\section{Materials}

Orthophenylenediamine, cinnamaldehyde, potassium thiocyanate, zinc nitrate, solvent (AnalaR grade) used as it is purchased from a chemical company. The synthesized ligand and zinc complex are stable and stored for a long time at room temperature.

\section{Methods}

Using Vario make EL-III model instrument at $950-1200^{\circ} \mathrm{C}$ temperature, predict the elemental analysis of the Schiff and complex. After decomposing the complex with a known weight, the metal ion was estimated by the gravimetric method. Melting point $\left({ }^{\circ} \mathrm{C}\right)$ was measured using Ajay melting point instrument in an open capillary tube. Molar conductance of the Schiff base and complex was measured in acetonitrile solution at $10^{-3} \mathrm{M}$ concentration at room temperature by the use of Systronic Conductivity Bridge. UVVisible spectra of complex and Schiff base were recorded in solid-state spectra (DRS method) on JASCOV650 made spectrometer in the range of 200-800 $\mathrm{nm}$. Using Shimadzu, FT-IR-4100 type-A model IR spectrometer, IR spectral study of ligand and its metal complex were recorded in the range of 4000 to $400 \mathrm{~cm}^{-1}$ as $\mathrm{KBr}$ pellet method. The Far IR spectra of the complex were recorded in a Bruker, Germany makes 3000 Hyperion Microscope with Vertex 80 FTIR system model instruments. Using Bruker instrument in DMSO-d6, the ${ }^{1} \mathrm{H}$ and ${ }^{13} \mathrm{C}-\mathrm{NMR}$ spectra of Schiff base and its diamagnetic $\mathrm{Zn}$ (II) complex were carried.

\section{Synthesis of Schiff Base}

The goal of green chemistry is to develop Eco-friendly synthetic reactions. Green chemistry involves the use of microwave technology, sonochemistry, phase transfer catalysis, ionic liquids, and many other techniques. The green chemical one-pot multicomponent condensation reaction of $0.486 \mathrm{~g}(4.40 \mathrm{mmol})$ of Orthophenylenediamine $(10 \mathrm{ml}$ ethanol $)$ and $0.624 \mathrm{~g}(4.70 \mathrm{mmol})$ of cinnamaldehyde $(10 \mathrm{ml}$ diethyl ether $)$ using water as a green solvent and stirred continuously for about 10-15 min at room temperature, the shiny powdered yellow color precipitate was formed. ${ }^{12}$ The obtained complex was purified by simple filtration followed by washing with water and drying in desiccators and the yield was (73.33\%) Scheme-1. This method is experimentally simple, clean, high-yielding, and green, with reduced reaction times.

\section{Synthesis of Zn(II) Complex}

Green route one-pot multicomponent reactions of a Schiff base, $0.75 \mathrm{~g},(3.36 \mathrm{mmol})$ in $20 \mathrm{ml}$ ethanol solution was mixed with zinc nitrate $(1 \mathrm{~g}, 3.36 \mathrm{mmol}$ in $10 \mathrm{ml}$ of methanol) and add anionic ligand viz., potassium thiocyanate $(0.65 \mathrm{~g}, 6.72 \mathrm{mmol}$ in $10 \mathrm{ml}$ of water $)$ was added. Then water used as a green solvent and stirred continuously for 10-15 min at room temperature yellow color precipitate was formed. The product was purified by simple filtration followed by washing with water and drying in desiccators and the yield was (87.87\%) Scheme-2.

Evaluation of Antibacterial Activity: Antibacterial activities of synthetic compounds such as Schiff base and its metal complex evaluated using well diffusion method with MHA. Under aseptic conditions, the MHA plates were inoculated. The test samples in the well were incubated at $37^{\circ} \mathrm{C}$ for 24 hours. After the incubation period, the diameter of the growth inhibition zones was measured. The antibacterial activity of the given compound was assessed against five bacterial species: Staphylococcus aureus, Escherichia coli, Vibrio parahaemolyticus, Pseudomonas aeruginosa and, Enterococcus and Candida albicans by agar well diffusion method. Each bacterial culture was grown in nutrient broth (bacterial) and potato dextrose broth (fungal) medium for 12 hours at $37^{\circ} \mathrm{C}$. Then, each grown culture was swabbed on nutrient agar medium and well were cut about $5 \mathrm{~mm}$ using a cork borer. Each well was added with $80 \mu 1$ of sample and incubated at $37^{\circ} \mathrm{C}$ for 18 hours. After incubation, the plates were observed for the zone of inhibition and it was measured. 
RASĀYAN J. Chem.

Vol. 14 | No. 2 |861-870| April - June | 2021

\section{Antioxidant (DPPH Free Radical Method)}

The free radical scavenging capacity of the plant extract was measured based on the method delineate by Brand-Williams et al (1995) with slight modification. $1 \mathrm{ml}$ of $0.1 \mathrm{mM} \mathrm{DPPH} \mathrm{solution} \mathrm{in} \mathrm{methanol} \mathrm{was} \mathrm{mixed}$ with $1 \mathrm{ml}$ of plant extract solution of varying concentrations $(10,100,500$ and $1000 \mu \mathrm{g} / \mathrm{ml})$. Blank samples were prepared and L-Ascorbic acid was used as standard. These tubes were thoroughly mixed and kept in the dark for $30 \mathrm{~min}$ and their absorbance was measured at $517 \mathrm{~nm}$ using UV-Visible spectrophotometer. The inhibition \% was calculated using the following formula:

\section{Inhibition $\%=\mathrm{Ac}-\mathrm{As} / \mathrm{Ac} \times 100$}

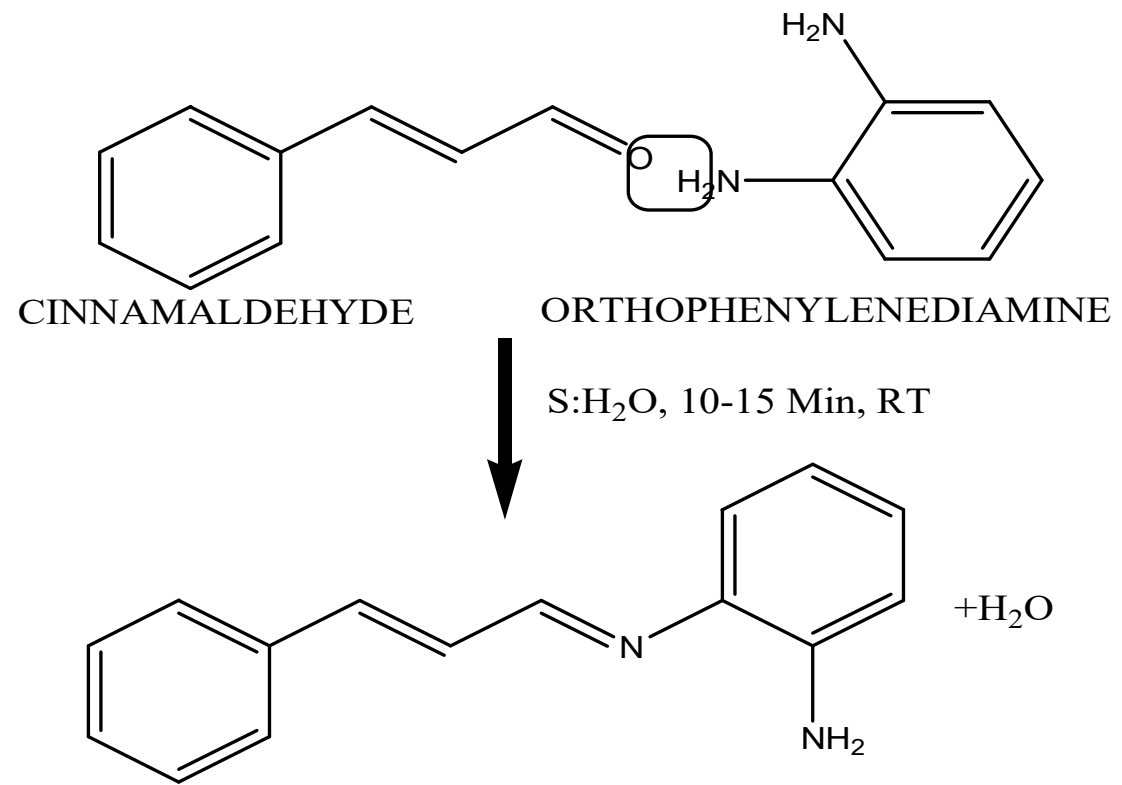

(E)-N1[(E)-3-PHENYLALLYLIDENE]BENZENE-1,2-DIAMINE

Scheme-1



(E)-N1[(E)-3-PHENYLALLYLIDENE]BENZENE-1,2-DIAMINE


(E)-N1[(E)-3-phenylallylidene]benzene-1,2-diaminedithiocyanato-kN-zinc(II) Scheme-2 
RASĀYAN J. Chem.

Vol. 14 | No. 2 |861-870| April - June | 2021

\section{Analytical Data}

\section{RESULTS AND DISSCUSSION}

The elemental analysis (C, H, N) of the Schiff base and its complex is shown in Table-1, the data which are in good agreement with calculated values. Based on the metal estimation of complex the stoichiometry and molecular formulae of the Schiff base and its complex are assessed as $\left[\mathrm{Zn}(\mathrm{SB})(\mathrm{SCN})_{2}\right]$. The molar conductance of $10^{-3} \mathrm{M} \mathrm{Zn}$ (II) complex shows the non-electrolytic (1:0 type) nature and no more anion and cations are present on its coordination sphere outside. ${ }^{13}$

\section{ESI Mass Spectra}

ESI mass spectrum of Schiff base recorded at room temperature. It is proposed that the empirical formula of the Schiff base and also support the stability of them. From the data of $\mathrm{m} / \mathrm{z}$ the value at 222 confirmed the molecular formulae of Schiff base $\left(\mathrm{C}_{15} \mathrm{H}_{14} \mathrm{~N}_{2}\right)$ but the fragments at 105 and 117 correspond to the $\mathrm{C}_{6} \mathrm{H}_{6} \mathrm{~N}_{2}{ }^{-}$and $\mathrm{C}_{9} \mathrm{H}_{8}{ }^{+}$respectively. ${ }^{14}$

Table-1: Physico-chemical Data of Schiff Base Complex

\begin{tabular}{|c|c|c|c|c|c|c|c|c|c|c|}
\hline \multirow[b]{2}{*}{ S. No. } & \multirow[b]{2}{*}{$\begin{array}{c}\text { Schiff base/ } \\
\text { Complex }\end{array}$} & \multirow{2}{*}{$\begin{array}{l}\text { Molecular } \\
\text { Weight } \\
(\mathrm{g} / \mathrm{mol})\end{array}$} & \multirow[b]{2}{*}{$\begin{array}{l}\mathrm{MP} \\
\left({ }^{\circ} \mathrm{C}\right)\end{array}$} & \multirow[b]{2}{*}{ Color } & \multicolumn{5}{|c|}{ Elemental Analysis } & \multirow{2}{*}{$\begin{array}{c}\text { Molar } \\
\text { Conductance } \\
\left(\mathrm{Ohm}^{-}\right. \\
{ }^{1} \mathrm{~cm}^{2} \mathrm{~mol}^{-1}\end{array}$} \\
\hline & & & & & $\% \mathrm{C}$ & $\% \mathrm{H}$ & $\% \mathrm{~N}$ & $\% \mathrm{~S}$ & $\% \mathrm{M}$ & \\
\hline 1 & Schiff base & 222.30 & 117 & $\begin{array}{l}\text { Shiny } \\
\text { yellow }\end{array}$ & $\begin{array}{c}80.97 \\
(80.19)\end{array}$ & $\begin{array}{c}6.29 \\
(6.30)\end{array}$ & $\begin{array}{c}12.59 \\
(12.52)\end{array}$ & - & - & 20.00 \\
\hline 2 & {$\left[\mathrm{Zn}(\mathrm{SB})(\mathrm{SCN})_{2}\right]$} & 403.83 & 230 & $\begin{array}{c}\text { Pale } \\
\text { Yellow }\end{array}$ & $\begin{array}{c}50.51 \\
(50.10)\end{array}$ & $\begin{array}{c}3.46 \\
(3.19)\end{array}$ & $\begin{array}{c}13.86 \\
(13.50)\end{array}$ & $\begin{array}{c}15.84 \\
(15.19)\end{array}$ & $\begin{array}{c}16.18 \\
(16.90)\end{array}$ & 14.28 \\
\hline
\end{tabular}

\section{UV Spectra}

The electronic spectra of Schiff base exhibit one broadband at the transition of $25,575 \mathrm{~cm}^{-1}$ shows the $\pi \rightarrow \pi^{*}$ whereas in the complex this transition present with related values confirming the imine bond of the Schiff base. The $\mathrm{Zn}$ (II) complex is diamagnetic its filled ' $\mathrm{d}$ ' shell shows only $\mathrm{n} \rightarrow \pi^{*}$ transition is also as being due to $\mathrm{C}=\mathrm{N}$ bond which is $\mathrm{C}-\mathrm{T}$ (charge transfer) band at $27,397 \mathrm{~cm}^{-1}$ confirming the square planar geometry. ${ }^{15}$

\section{IR and Far-IR Spectra}

IR spectra are the main tool to find out the functional group present in the ligand and its entry into the coordination sphere. Determine the binding site of Schiff base to the metal ion in the complex. IR spectrum of the free ligand was compared with the spectrum of the metal complex (Fig.-1). The spectral data of the Schiff base showed the appearance of a new band at $1595 \mathrm{~cm}^{-1}$ due to the Schiff base azomethine linkage formation. In $\mathrm{Zn}(\mathrm{II})$ complex the $v(\mathrm{C}=\mathrm{N})$ stretching frequency shifted to higher values at $1628 \mathrm{~cm}^{-1}$ indicate the metal ions are coordinate with the free Schiff base through an azomethine nitrogen atom. There are two aromatic rings $v(\mathrm{C}-\mathrm{H})$ are present in the Schiff base at 3371 and $3142 \mathrm{~cm}^{-1}$. In complexes, one of the values are shifted to the lower region at $3206 \mathrm{~cm}^{-1}$ but the other frequencies were also changed at $3186 \mathrm{~cm}^{-1}$ due to the effective coordination through the imine nitrogen atom which is attached in one aromatic ring, the other amine group chelated to metal ions is confirmed by the $v(\mathrm{~N}-\mathrm{H})$ at $3500 \mathrm{~cm}^{-1}$ while in complex these values shifted to $3437 \mathrm{~cm}^{-1}$. The C-N stretching frequency of Schiff base is at $1398 \mathrm{~cm}^{-1}$ which is also shifting to the higher frequency at $1402 \mathrm{~cm}^{-1}$ in a metal complex which is further evidence of coordination of metal ion through imine nitrogen. ${ }^{16,17}$ The mixed anionic ligand thiocyanate ion coordinated through nitrogen or Sulphur to the metal ion. If it is coordinated through "N" it is N-bonded at below $2100 \mathrm{~cm}^{-1}$ whereas through "S" it is above $2100 \mathrm{~cm}^{-1}$. In metal complexes, the $v(\mathrm{SCN})$ stretching frequency at 2068 $\mathrm{cm}^{-1}$ was confirmed by the coordination of metal ions through the ' $\mathrm{N}$ ' atom of thiocyanate ion and not from its Sulphur atom. ${ }^{18}$ In far-IR spectra, the low frequencies at $419 \mathrm{~cm}^{-1}$ and $526 \mathrm{~cm}^{-1}$ corresponding to the M$\mathrm{N}$ coordination bonds of imine and amino group of Schiff base to the metal complex. The frequency at 489 $\mathrm{cm}^{-1}$ shows the M-N coordination bond of thiocyanate additional ligand in the complex. ${ }^{19}$

\section{NMR Spectra of Ligand and Zn(II) Complex \\ Proton NMR}

Proton NMR spectrum of Schiff base was carried out in DMSO they appeared signal of the aromatic proton was found to be in the expected region of them. The azomethine $\mathrm{N}=\mathrm{C}-\mathrm{H}$ proton shows the chemical shift 
RASĀYAN J. Chem.

Vol. 14 | No. 2 |861-870| April - June | 2021

value at 8.42 to $8.43 \mathrm{ppm}$ and $\mathrm{NH}_{2}$ proton appeared at $5.05 \mathrm{ppm}$. The aromatic chemical shift values of Schiff base are $7.44 \mathrm{ppm}\left(\mathrm{C}--\mathrm{H}_{1}\right), 7.38 \mathrm{ppm}\left(\mathrm{C}--\mathrm{H}_{2}\right), 7.65-7.66 \mathrm{ppm}\left(\mathrm{C}--\mathrm{H}_{3}\right) 7.17 \mathrm{ppm}\left(\mathrm{C}--\mathrm{H}_{4}\right) 7.11 \mathrm{ppm}$ $\left(\mathrm{C}-\mathrm{H}_{5}\right) 6.69-6.70 \mathrm{ppm}\left(\mathrm{C}-\mathrm{H}_{8}\right) 6.57-6.58 \mathrm{ppm}\left(\mathrm{C}-\mathrm{-H}_{9}\right) 6.97$-6.98ppm $\left(\mathrm{C}-\mathrm{-H}_{10}\right)$ and 7.0-7.03 $\left(\mathrm{C}-\mathrm{H}_{11}\right)$. In $\mathrm{Zn}$ (II) complex all the chemical shift values of the proton slightly shifted to a down or up-field (Fig.-2 and 4) due to the de-shielding and increasing the conjugation in the chelates ring. ${ }^{20}$

\section{${ }^{13} \mathrm{C}-\mathrm{NMR}$}

${ }^{13} \mathrm{C}$-NMR spectrum of Schiff base gives the chemical shift values of different carbon atoms. Azomethine carbon atom found at $158.79 \mathrm{ppm}$ whereas $\mathrm{Zn}$ (II) complex is slightly shifted to $158.93 \mathrm{ppm}$, the $\mathrm{N}_{\mathrm{H} 2}$ carbon atom chemical shift value in Schiff base is $144.02 \mathrm{ppm}$ in $\mathrm{Zn}(\mathrm{II})$ complex it is shifted to upfield region at 143.84 ppm. (Fig.-3 and 5) All the other chemical shift values of carbon atom slightly shifted to down or upfield..$^{21}$



Fig.-1: FT-IR Spectra of Free Ligand and Zn(II) Complex

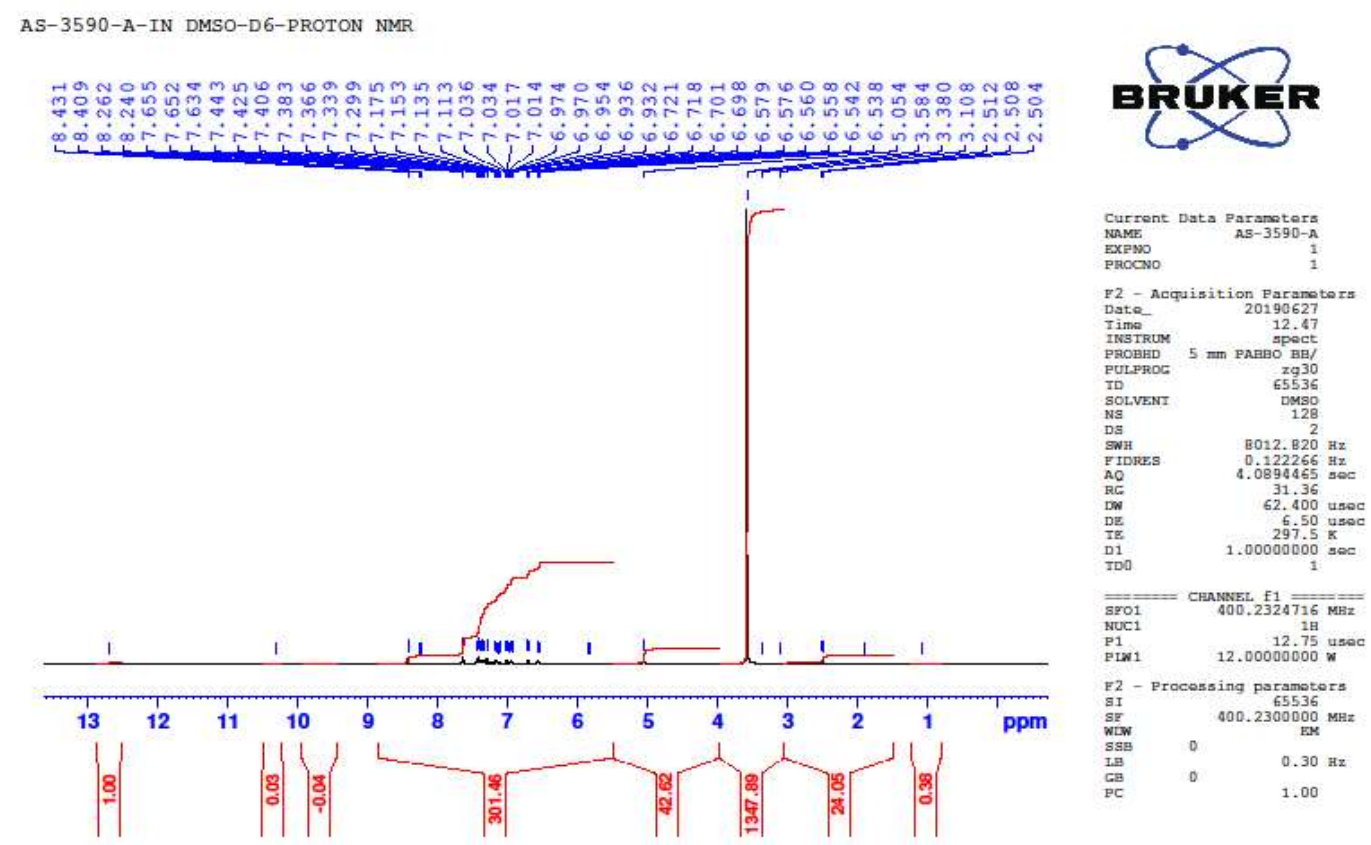

Fig.-2: ${ }^{1} \mathrm{H}-\mathrm{NMR}$ Spectrum of (E)-N1[(E)-3-phenylallylidene]benzene-1,2-diamine 865 
RASĀYAN J. Chem.

Vol. 14 | No. 2 |861-870| April - June | 2021
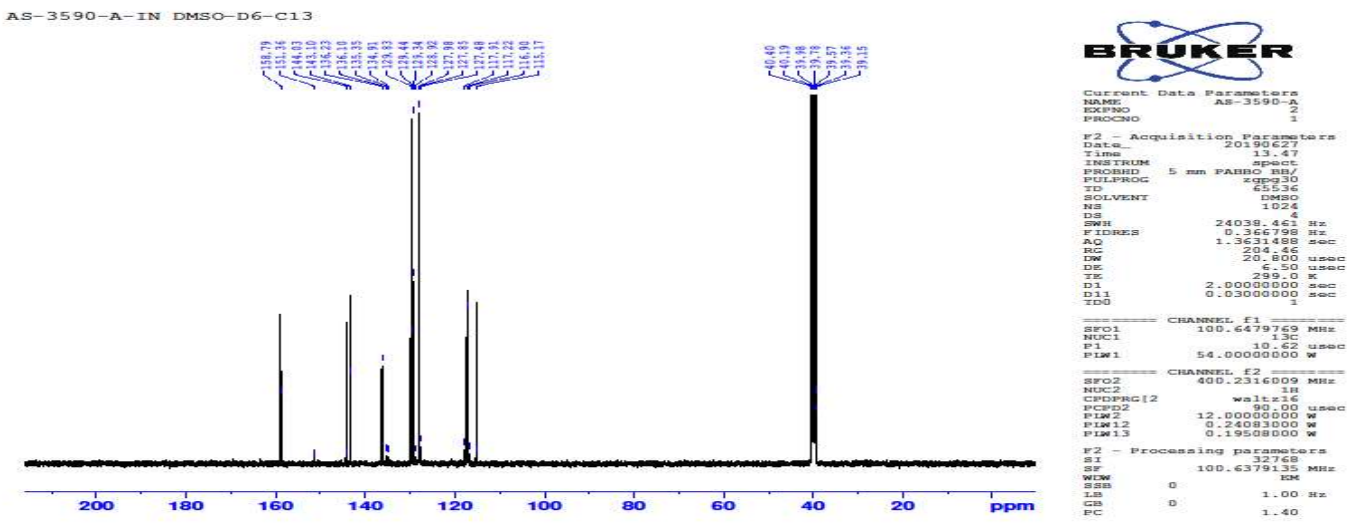

Fig.-3: ${ }^{13}$ C-NMR Spectrum of (E)-N1[(E)-3-phenylallylidene]benzene-1,2-diamine
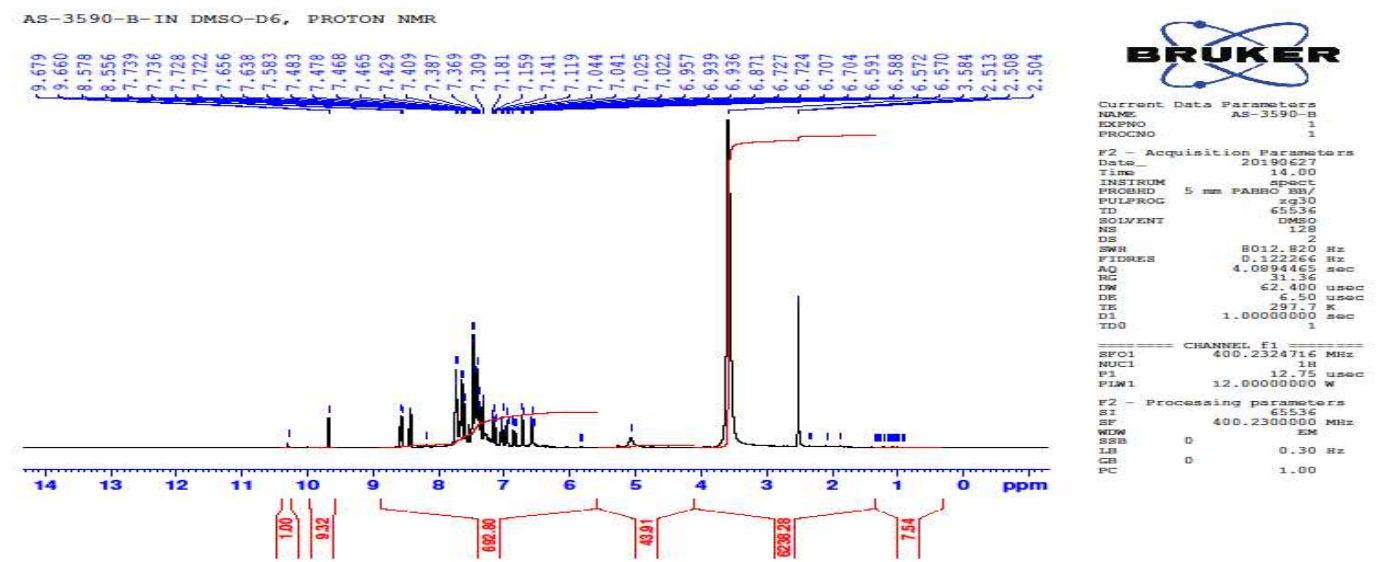

Fig.-4: ${ }^{1} \mathrm{H}-\mathrm{NMR}$ Spectrum of diamagnetic Zn(II) Complex
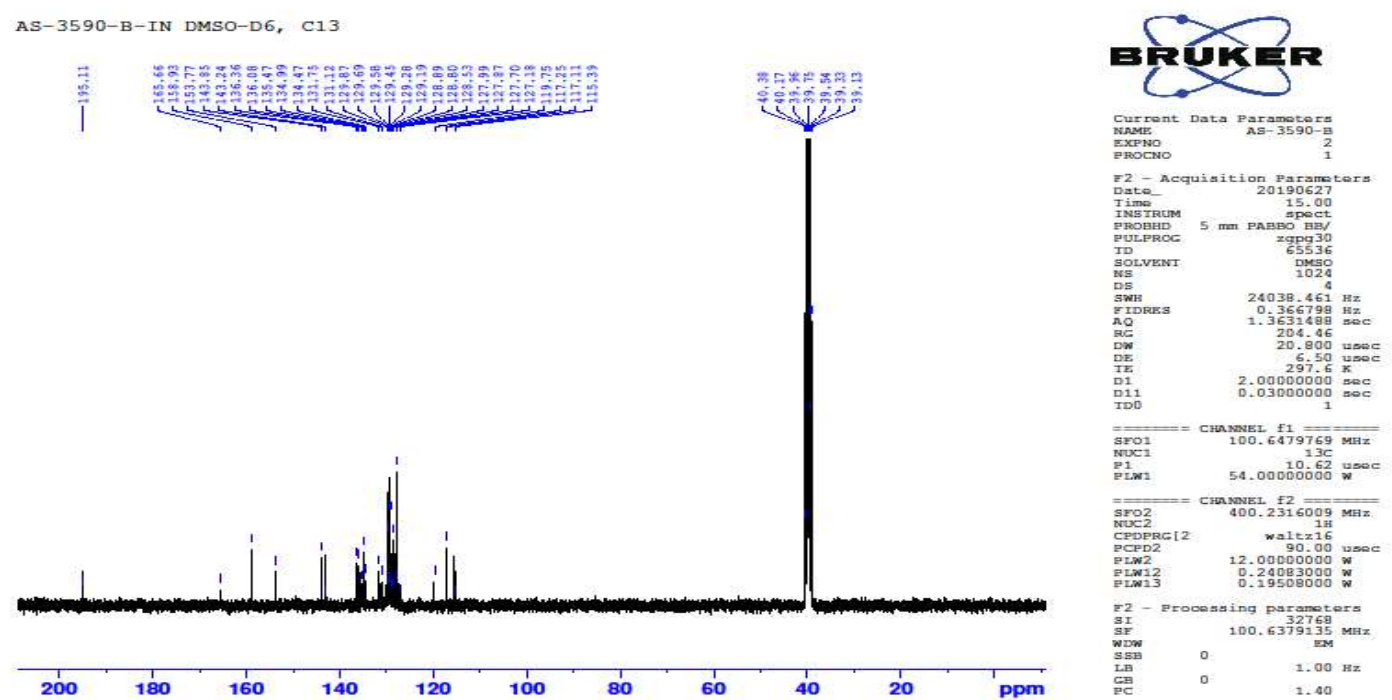

Fig.-5: ${ }^{13} \mathrm{C}-\mathrm{NMR}$ Spectrum of Diamagnetic Zn(II) Complex 
RASĀYAN J. Chem.

Vol. 14 | No. 2 |861-870| April - June | 2021

\section{Antibacterial and Antifungal Activities}

The synthesized Schiff base metal(II) complex were subjected to in-vitro biological activities viz., antibacterial and antifungal using bacterial and fungal strains viz., S. Aureus and Enterococcus, three-gram negative bacteria such as E.coli, Vibrio parahaemolyticus and P.aeruginosa and C. albicans by Agar well diffusion method (Fig.-6). The MIC values (Table-2) of the microorganisms predicted which indicating the Schiff base and its $\mathrm{Zn}$ (II) complex exhibit bio-potential activity. The antibacterial and antifungal activity of the $\mathrm{Zn}(\mathrm{II})$ complex is highly active for $S$. Aureus and C. albicans but moderately active for the other microorganisms than the Schiff base. The increased activity of the metal chelates may be explained on basis of Tweedy chelation theory. The chelation of metal complexes acts as a powerful and bactericidal agent. That chelation killing more bacteria, the positive charge on the metal ion is partially shared with the ligand. There may be a $\pi$ electron delocalization in the chelates ring is present which increase the lipophilicity which increases the enhanced bio-potential activities, solubility, conductivity and bond parameters are also increase the activity of metal complexes. ${ }^{22}$

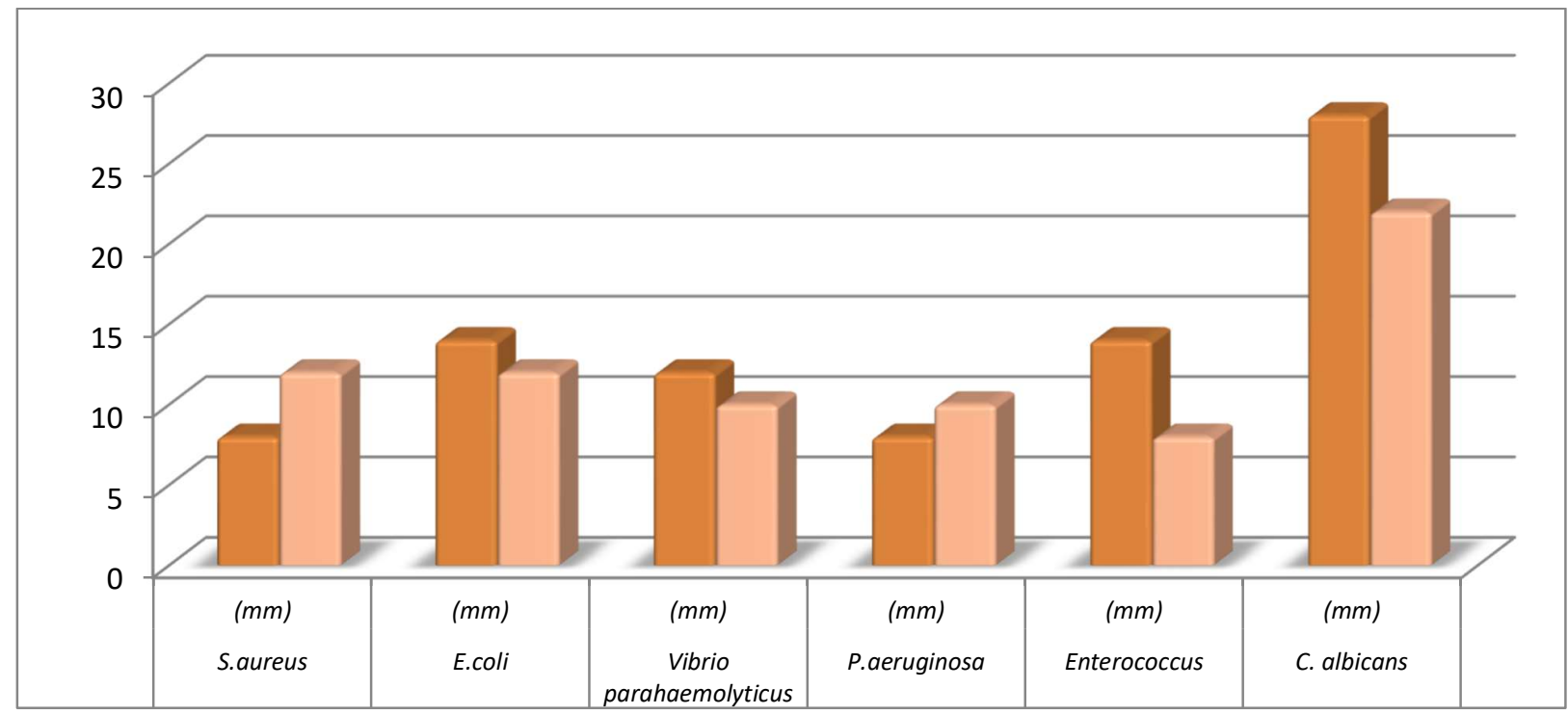

Fig.-6: Antibacterial and Antifungal Comparative Study Schiff base and Zn(II) complex

Table-2: Bio-potential Activities of Free Ligand and its Complex

\begin{tabular}{r|c|c|c|c|c|c|c}
\hline & Table-2: Bio-potential Activities of Free Ligand and its Complex \\
\hline S. No. & Compound & $\begin{array}{c}\text { S. aureus } \\
(\mathrm{mm})\end{array}$ & $\begin{array}{c}\text { E. coli } \\
(\mathrm{mm})\end{array}$ & $\begin{array}{c}\text { Vibrio } \\
\text { parahaemolyticus } \\
(\mathrm{mm})\end{array}$ & $\begin{array}{c}\text { P. aeruginosa } \\
(\mathrm{mm})\end{array}$ & $\begin{array}{c}\text { Enterococcus } \\
(\mathrm{mm})\end{array}$ & $\begin{array}{c}\text { C. albicans } \\
(\mathrm{mm})\end{array}$ \\
\hline 1 & Schiff base & 08 & 14 & 12 & 08 & 14 & 28 \\
\hline 2 & $\begin{array}{c}\mathrm{Zn}(\mathrm{II}) \\
\text { Complex }\end{array}$ & 12 & 12 & 10 & 10 & 08 & 22 \\
\hline
\end{tabular}

\section{Antioxidant Activity}

Antioxidant activity of Schiff base and Zn(II) complex was determined by DPPH free radical scavenging method. The free radical scavenging activity of compounds was carried out at different concentrations (10$1000 \mu \mathrm{g} / \mathrm{ml})$. L-Ascorbic acid is used as a standard. The percentage inhibition was measured from the absorption of control and samples. The result of scavenging activity shows the maximum free radical scavenging activity at $74.10 \%$ and $72.30 \%$. The IC50 value of the Schiff base is 359.3 but in $\mathrm{Zn}$ (II) complex it is 357.0 (Fig.-7) which is higher than the standard. Comparing the standard Schiff base and complex shows antioxidant activity at higher concentrations. It is observed that they have $50 \%$ scavenging activity. ${ }^{23}$, 24

\section{Physico-chemical and General Computational Methodology}

The SMILES for Schiff base and Zn(II) complex generate structure file generator from online tool Swiss ADME web page. Using the web tool the physicochemical descriptors, such as the molecular weight (MW), 
RASĀYAN J. Chem.

Vol. 14 | No. 2 |861-870| April - June | 2021

molecular refractivity (MR), count of specific atom types and the topological polar surface area (TPSA), the latter proven as a useful descriptor in many models for estimation of membrane diffusion, ADME and pharmacokinetic behavior. The lipophilicity was assessed using five alternative predictive models; i.e. $\mathrm{X} \log \mathrm{P}$; W $\log \mathrm{P}$; MlogP; SILICOS-IT, ilogP, together with a consensus $\log \mathrm{P}$ estimation, based on the average value of the different computational parameters (Table-3,4 and 5).

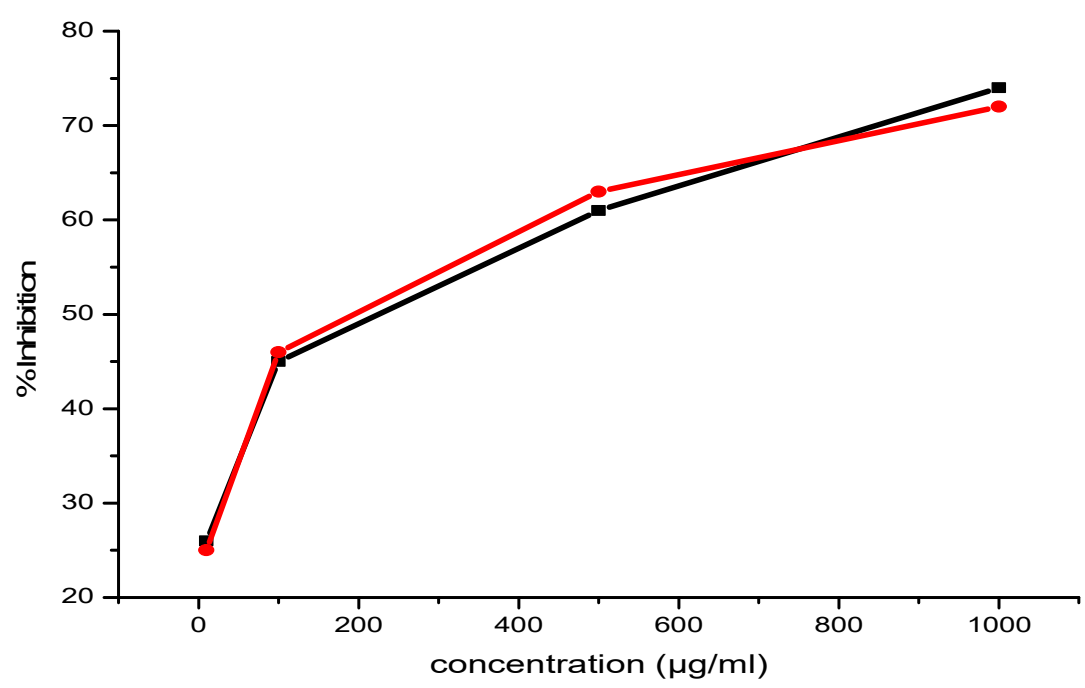

Fig.-7: Antioxidant \% Inhibition of Schiff base and Zn(II) Complex

Table-3: Physico-chemical Parameters

\begin{tabular}{c|c|c|c}
\hline S. No. & Parameters & Schiff base & {$\left[\mathrm{Zn}(\mathrm{SB})(\mathrm{SCN})_{2}\right]$} \\
\hline & & & \\
\hline 1 & Formula & $\mathrm{C}_{15} \mathrm{H}_{14} \mathrm{~N}_{2}$ & $\mathrm{C}_{17} \mathrm{H}_{14} \mathrm{~N}_{4} \mathrm{~S}_{2} \mathrm{Zn}$ \\
\hline 2 & Molecular weight & $222.29 \mathrm{~g} / \mathrm{mol}$ & $403.83 \mathrm{~g} / \mathrm{mol}$ \\
\hline 3 & Num. heavy atoms & 17 & 24 \\
\hline 4 & $\begin{array}{c}\text { Num. atom. heavy } \\
\text { atoms }\end{array}$ & 12 & 12 \\
\hline 5 & Fraction Csp3 & 0.00 & 0.00 \\
\hline 6 & Num. rotatable bonds & 3 & 3 \\
\hline 7 & Num. H-bond acceptors & 1 & 3 \\
\hline
\end{tabular}

Table-4: Lipophilicity

\begin{tabular}{c|c|c|c}
\hline 1 & GI absorption & High & High \\
\hline 2 & BBB permeant & Yes & No \\
\hline 3 & P-gp substrate & No & Yes \\
\hline 5 & $\begin{array}{c}\text { CYP1A2 } \\
\text { inhibitor }\end{array}$ & Yes & No \\
\hline 6 & $\begin{array}{c}\text { CYP2C19 } \\
\text { inhibitor }\end{array}$ & Yes & No \\
\hline 7 & $\begin{array}{l}\text { CYP2C9 } \\
\text { inhibitor }\end{array}$ & Yes & No \\
\hline 8 & $\begin{array}{l}\text { CYP2D6 } \\
\text { inhibitor }\end{array}$ & No & No \\
\hline 9 & $\begin{array}{c}\text { CYP3A4 } \\
\text { inhibitor }\end{array}$ & Yes & No \\
\hline permeation) & $\begin{array}{c}-5.55 \\
\mathrm{~cm} / \mathrm{s}\end{array}$ & $\begin{array}{c}-5.85 \\
\mathrm{~cm} / \mathrm{s}\end{array}$ \\
\hline
\end{tabular}


RASĀYAN J. Chem.

Vol. 14 | No. 2 |861-870| April - June | 2021

The medicinal chemistry and drug properties of the compounds were also assessed and the results indicating the Schiff base and its complex are used as a drug in the field of medicinal chemistry. In Pharmacokinetics study the blood-brain barrier is absent but GI absorption is high which leads to high lipophilicity of the compounds shows high Pharmokinetics and drug likeliness properties. ${ }^{25-27}$

Table-5: Pharmacokinetics

\begin{tabular}{c|c|c|c}
\hline 1 & $\log P_{\mathrm{o} / \mathrm{w}}(\mathrm{i} \log \mathrm{P})$ & 2.61 & -44.74 \\
\hline 2 & $\log P_{\mathrm{o} / \mathrm{w}}(\mathrm{X} \log \mathrm{P} 3)$ & 2.97 & 4.10 \\
\hline 3 & $\log P_{\mathrm{o} / \mathrm{w}}(\mathrm{W} \log \mathrm{P})$ & 3.58 & 3.61 \\
\hline 4 & $\log P_{\mathrm{o} / \mathrm{w}}(\mathrm{M} \log \mathrm{P})$ & 3.05 & 1.66 \\
\hline 5 & $\log P_{\mathrm{o} / \mathrm{w}}(\mathrm{SILICOS}-\mathrm{IT})$ & 3.67 & 3.67 \\
\hline 6 & Consensus $\log P_{\mathrm{o} / \mathrm{w}}$ & 3.18 & -6.34 \\
\hline
\end{tabular}

\section{CONCLUSION}

The Schiff base (E)-N1[(E)-3-phenylallylidene]benzene-1,2-diamine and Zn(II) complex was synthesized by high efficient green route method with a higher yield. The Schiff base coordinated to the metal ion through its imine and amino nitrogen by bidentate mode to form metal chelates, based on the analytical and spectral data (UV-Visible, IR, Far-IR, Mass spectra and NMR) reports confirmed the mononuclear, nonelectrolytic and square planar geometry of Zn(II) complex. The Schiff base is high potential to the screened microorganisms but the complexes are highly active for some microorganisms and moderately active against the growth of other microorganisms. The antioxidant activity of the Schiff base and $\mathrm{Zn}$ (II) complex shows $50 \%$ scavenging activity.

\section{ACKNOWLEDGMENT}

The authors are very much grateful to the Principal, and Head Department of Chemistry, Govt. Arts College, Ariyalur for providing facilities available at the Department. We are indebted to the Head and Staff members of SAIF Chennai, Mumbai, STIC Cochin, Harman Research Institute, for providing spectral and biological activities of compounds.

\section{REFERENCES}

1. Fatma N. Sayed, Walaa H. Mahmoud, M. M. Omar and Gehad G. Mohamed, Applied Organometallic Chemistry, 33, e5143(2019), DOI:10.1002/aoc.5143

2. Wenling Qin, Sha Long, Mauro Panunzio and Stefano Biondi, Molecules, 18(10), 12264(2013), DOI: $10.3390 /$ molecule 181012264

3. S. Pattanaik, S. S. Rout, J. Panda, P. K. Sahu and M. Banerjee, Rasayan Journal of Chemistry, 4(1), 136(2011).

4. Shubhangi N. Kotkar and Harjeet D. Juneja, Journal of Chemistry, 2013, 1(2013), DOI: $10.1155 / 2013 / 479343$

5. N. Raman, C. Thangaraja and S. Johnsonraja, Central European Journal of Chemistry, 3(3), 537 (2005),DOI:10.2478/BF02479281

6. P.G. Cozzi, Chemical Society Reviews, 33, 410(2004), DOI:10.1039/B307853C

7. Alka Choudhary, Renu Sharma, Meena Nagar and Mohammed Mohsin, Journal of Enzyme Inhibition and Medicinal Chemistry, 26(3), 394 (2011), DOI:10.3109/14756366.2010.518966

8. U.K. Sharma, A. K. Sharma and A. K. Pandey, BMC Complementary and Alternative Medicine 16(156), 1(2016), DOI:10.1186/s12906-016-1147-4

9. Dhanushka Gunawardena, Niloo Karunaweera, Samiuela Lee, Frank van Der Kooy, David G. Harman, Ritesh Raju, Louise Bennett, Erika Gyengesi, Nikolaus J. Sucher and Gerald Münch, Food \& Function, 1(2015), DOI:10.1039/c4fo00680a

10. Trissa Joseph S. B. Halligudi, C. Satyanarayan, Dhanashree P. Sawant and S. Gopinathan, Journal of Molecular Catalysis A: Chemical,168,87(2001), DOI:10.1016/S1381-1169(00)00443-X

11. Josko Osredkar and Natasa Sustar, Journal of Clinical Toxicology, S:3, 1(2011), DOI:10.4172/21610495.S3-001

12. V. K. Rao, S. S. Reddy, B. S. Ktishna M.K. R Naidu, C.N Raju and S. K. Ghosh, Green Chemistry Letter and Review, 3(3), 217(2010), DOI:10.1080/17518251003716550 
RASĀYAN J. Chem.

Vol. 14 | No. 2 |861-870| April - June | 2021

13. Sahdeo Kumar, Pawan K. Pandey, Navneet Sinha, Sudama Chaundhari and Shivadhar Sharma, Journal of Physical Science, 29, 1(2018), DOI:10.21315/jps2018.29.3.1

14. A.P. Mishra, R. K. Mishra and S. P. Shrivastava, Journal of Serbian Chemical Society, 74(5), 523(2009), DOI: 10.2298/JSC0905523M

15. Mohamed Gaber, Hoda A. EL-Ghamry, Shaimaa K. Fathalla, Mohammed A. Mansour, Material Science and Engineering, C:83, 78(2018), DOI:10.1016/j.msec.2017.11.004

16. Md. Kudrat-E-Zahan, Md. Abul Bashar, Md. Faruk Hossen and M. Saidul Islam, Asian Journal of Researchin Chemistry, 8(2), 74(2015), DOI:10.5958/0974-4150.2015.00015.2

17. T. M. Fasina, O. Ogundele, F. N. Ejiah and C. U. Dueke-Eze, International Journal of Biological Chemistry, 6, 24(2012), DOI:10.3923/ijbc.2012.24.30

18. Aliakbar Dehno Khalaji, Hossein Mighani, Kazuma Gotoh Hiroyuki Ishida, Journal of Chemical Crystallogrphy, 41, 1154(2011), DOI:10.1007/s10870-011-0062-2

19. S. Sathiyaraj, G. Ayyannan and C. Jayabalakrishnan, Journal of Serbian Chemical Society, 79(2), 151(2014), DOI: 10.2298/JSC121201073S

20. M. S. Refat, M. Y. EL-Sayed, and A. M. A. Adam, Journal of Molecular Structure, 1038, 62(2013), DOI: $10.1016 /$ j.molstruc.2013.01.059

21. M. L. Sundarrajan, T. Jeyakumar, J. Ananthakumaran and B. K. Selvan, Spectrochimi. Acta Part-A Molecular and Biomolecular Spectroscopy, 131, 82(2014), DOI:10.1016/j.saa.2014.04.055

22. N. Raman, J. Dhaveethu Raja and A. Sakthivel, Journal of Chemical Science, 119, 303(2007), DOI: $10.1007 / \mathrm{s} 12039-007-0041-5$

23. Pinar Alper, Mervi Erkisa, Hasene Mutlu Genckal, Saliha Sahin, Engin Ulukaya and Ferda Ari, Journal of Molecular Structure, 1196, 783(2019), DOI:10.1016/j.molstruc.2019.07.009

24. Sabari Dutta, Ratnamala Bendre, Subhash Padhye, Fakhara Ahmed and Fazlul Sarkar, Synthesis and Reactivity in Inorganic, Metal-organic and Nano-metal Chemistry, 35(1), 3(2005), DOI:10.1081/SIM200047494

25. Swiss ADME: A Free Web Tool to Evaluate Pharmacokinetics, Drug-likeness and Medicinal Chemistry Friendliness of Small Molecules, Scientific Report, 7, 42717(2017).

26. iLOGP: A Simple, Robust, and Efficient Description of $n$-octanol/water partition coefficient for drug design using the GB/SA approach, Journal of Chemical Information Model, 54(12), 3284(2014).

27. Antoine Daina and Vincent Zoete, ChemMedChem, 6(11), 1117(2016), DOI: $10.1002 / \mathrm{cmdc} .201600182$

[RJC-6264/2020] 